Vol. $8 \mid 20$ | International Journal of

NN1 21 Medical and Surgical Sciences

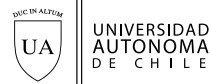

Short Communication

\title{
Correlation Between RaINFAll AND THE PREVALENGE OF SGRUB TYPHUS: AN OBSERVATION FROM A TROPICAL ENDEMIC COUNTRY
}

\section{Correlación entre las precipitaciones y la prevalencia del tifus de matorral: una observación de un país endémico para enfermedades tropicales}

\author{
Rujittika MungmungPuntipantip (i) \\ Private Academic Consultant, Bangkok, Thailand \\ Viroj WiWANitKit [1] \\ Honorary professor, Dr DY Patil University, Pune, India \\ Correspondence: Dr Rujittika Mungmunpuntipantip \\ Private Academic Consultant, Bangkok, Thailand \\ Email: rujittika@gmail.com
}

\begin{abstract}
The effect of climatological parameter on infectious disease is an interesting issue in clinical epidemiology. Of several parameters, rainfall is reported for its interrelationship with many tropical diseases such as malaria. In this short communication, the authors report the observation on correlation between rainfall and the prevalence of scrub typhus from a tropical endemic country.
\end{abstract}

Key words: Scrub Typhus; Rainfall; Correlation 


\section{Introduction}

Arthropod borne disease is an important public health problem in the tropical countries (Maye, et al., 2017). There are many kinds of arthropod borne infectious diseases. Those diseases can bring acute febrile illness and become important public health problem in tropical medicine. To manage those diseases, epidemiological data is useful for prediction of disease pattern and planning for appropriate correspondence (Ogden, 2017).

The local background data analysis is useful for further implication in clinical epidemiology. The analysis of background climate and its effect is useful for management of local endemic disease. In this article, the authors report on observation on correlation between rainfall and the prevalence of scrub typhus from a tropical endemic country in Indochina. The tropical disease that is studied in the present work is scrub typhus, which is an endemic tropical arthropod borne disease in Indochina (Low, et al., 2020). In Indochina, meteorological background, hot and humid, can promote the spreading of this disease.

\section{Materials and Methods}

The authors hereby use a standard medical geography technique to assess the correlation between prevalence of scrub typhus and rainfall in Thailand, a tropical country in Indochina Using the same technique described in the previous studies of the team of authors (Wiwanitkit, 2006; Wiwanitkit \& Wiwanitkit, 2016; Wangrangsimakul, et al., 2020).

The primary data include a) the data on prevalence of scrub typhus from Center of Disease Control, Ministry of Public Health, Thailand (Available online at http://epid.moph.go.th, Accessed 30 November 2020) and b) data on average rainfall (Royal Irrigation Department Thailand. Available online at http://www.rid.go.th/bid/bid.html, Accessed 130 November 2020). The most update from year 2019 is used in the present study.

\section{Results}

From analysis on primary data, averages for prevalence of scrub typhus and rainfall, are equal to $1.3(/ 100,000)$ and 9.1 (inches) respectively. In this study, the derived least square equation plot prevalence of scrub typhus $(\mathrm{Y})$ versus rainfall $(\mathrm{X})$ is as this equation " $\mathrm{Y}=8.12 \mathrm{X}-1.58(\mathrm{r}=0.64, p<$ 0.05)."

Further geographical information system (GIS) analysis is done for contribution of GIS map and the derived map showing the predicted prevalence of scrub typhus based on rainfall distribution is shown in Figure 1. The prevalence from GIS map ranges from 0 to 23 with the highest peak at the northern region of the country. 
Figure 1.

GIS map showing predicted prevalence of scrub typhus based on rainfall distribution in Thailand.
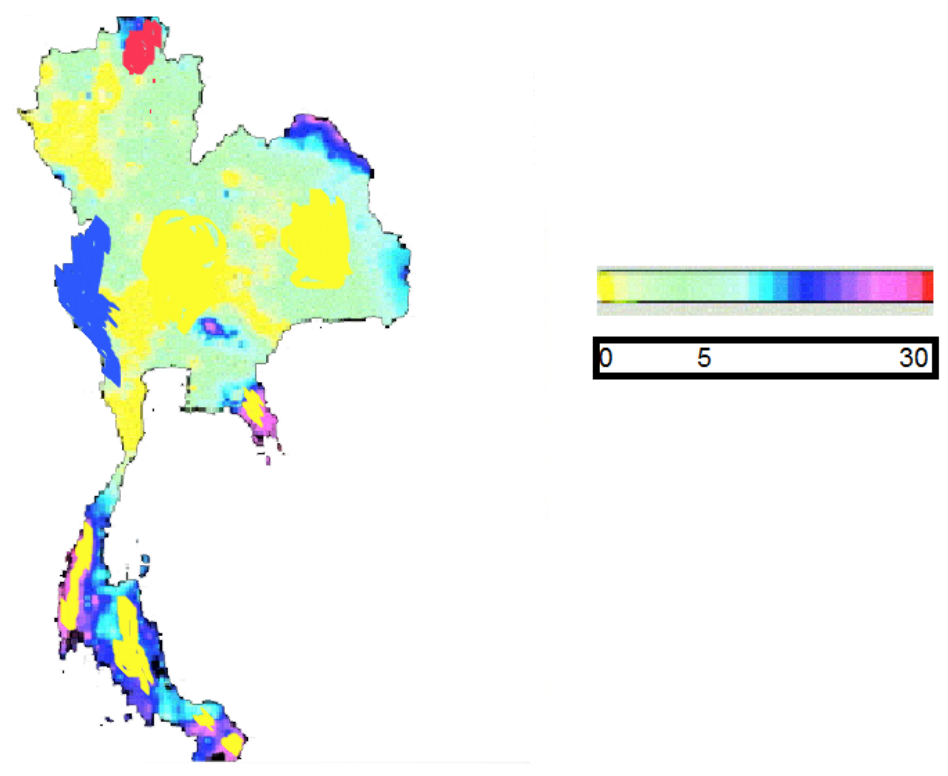

\section{Discussion}

The effect of climatological parameter on infection is an interesting issue in clinical epidemiology. Rainfall is a meteorological factor that is mentioned for the interrelationship with many tropical diseases such as malaria (Wiwanitkit, 2006a), dengue (Wiwanitkit, 2006b) and Zika virus infection (Wiwanitkit \& Wiwanitkit, 2016). In this work, the correlation between the rainfall and the prevalence of scrub typhus is investigated. The setting is a tropical endemic area of the disease and the local climate background is as a tropical monsoon with average rainfall equal to 10.5 inches.

In this work, it can confirm the effect of background rainfall on the prevalence of disease. The identified risk area, the northern region is concordant with the previous surveillance report from Thailand (Wangrangsimakul et al., 2020). Nevertheless, it should note that there might be other local factors that can also affect the prevalence of disease. The examples of those factors are the use of anti-insect agent and the local intensity of disease control program.

\section{Conflict of interest}

None

\section{Funding}

None 


\section{References}

Low VL, Tan TK, Khoo JJ, Lim FS, AbuBakar S. (2020). An overview of rickettsiae in Southeast Asia: Vector-animal-human interface. Acta Trop. 2020 Feb; 202:105282. https://doi.org/10.1016/j. actatropica.2019.105282

Mayer SV, Tesh RB, Vasilakis N. (2017). The emergence of arthropod-borne viral diseases: A global prospective on dengue, chikungunya and zika fevers. Acta Trop. 2017 Feb;166:155-163. https:// doi.org/10.1016/j.actatropica.2016.11.020

Ogden NH. (2017) Climate change and vector-borne diseases of public health significance. FEMS Microbiol Lett. 2017 Oct 16;364(19). https://doi.org/10.1093/femsle/fnx186

Wangrangsimakul, T; Elliott, I; Nedsuwan, S; Kumlert, R; Hinjoy, S; Chaisiri, K; Day, NPJ1; Morand S. (2020). The estimated burden of scrub typhus in Thailand from national surveillance data (20032018). PLoS Negl Trop Dis. 2020 Apr 14;14(4):e0008233. https://doi.org/10.1371/journal. pntd.0008233

Wiwanitkit, S; Wiwanitkit, V.(2016). Predicted pattern of Zika virus infection distribution with reference to rainfall in Thailand. Asian Pac J Trop Med. 2016 Jul;9(7):7 19-20. https://doi.org/10.1016/j. apjtm.2016.05.014

Wiwanitkit V. (2006a). Correlation between rainfall and the prevalence of malaria in Thailand. J Infect 2006a; 52:227-30. https://doi.org/10.1016/j.jinf.2005.02.023

Wiwanitkit, V.(2006b). An observation on correlation between rainfall and the prevalence of clinical cases of dengue in Thailand. J Vector Borne Dis. 2006b Jun;43(2):73-6. https://pubmed.ncbi.nlm. nih.gov/16967819/

\section{RESUMEN}

El efecto del parámetro climatológico en las enfermedades infecciosas es un tema interesante en la epidemiología clínica. De varios parámetros, se reportan precipitaciones por su interrelación con muchas enfermedades tropicales como el paludismo. En esta breve comunicación, los autores informan de la observación sobre la correlación entre las precipitaciones y la prevalencia del tifus de matorral de un país endémico tropical.

Palabras clave: Tifus de los matorrales; Precipitaciones; Correlación 